\title{
The Danian and Selandian calcareous benthic foraminiferal assemblages and biostratigraphy of Western Siberia
}

\author{
Vera Podobina \\ Tomsk State University, 36 Lenin Ave., Tomsk, 634050 Russia; e-mail: podobina@ggf.tsu.ru
}

\begin{abstract}
Danian and Selandian successions in western Siberia are rich in calcareous benthic foraminifers. The assemblages with a constant systematic composition that have the widest lateral occurrence are distinguished as foraminiferal zones. The Brotzenella praeacuta Zone was established in the low-carbonate, clayey beds that form the transition from the Gankinskaya Suite to the Talitskaya Suite. These transitional beds are assigned to the Danian. The calcareous benthic foraminifers in this zone occur mainly together with agglutinated forms. The zone is traced along the areas of the largest subsidence of the Mesozoic-Cenozoic basin, principally in depressions. The transition from the Cretaceous to the Palaeogene is represented by a continuous succession, in which the Danian deposits escaped from erosion and were found to contain the B. praeacuta assemblage. In Danian rocks with a shallow-marine facies (near Beryozovo and in the Ust'-Tym depression, Fig. 1), the Bathysiphon nodosarieformis - Glomospira charoides assemblage occurs. It is dominated by primitive forms in addition to more advanced tests (mainly Late Maastrichtian relic species).

The overlying Selandian (Middle Palaeocene) foraminiferal assemblages are assigned to the Talitskaya Suite. The Ammoscalaria friabilis assemblage is widely spread and is represented mainly by agglutinated quartz-siliceous forms. Beds with these species are attributed to the Ammoscalaria friabilis Zone, which can be correlated with beds in the East containing Cyclammina coksuvorovae. The Cibicidoides proprius assemblage is known from the lower and middle beds of the Talitskaya Suite in Transuralia, the Omsk Depression and more south-eastern areas; the species of this assemblage are characteristic of the Selandian.
\end{abstract}

Keywords: benthic foraminifera, Danian, Selandian, Western Siberia

\section{Introduction}

The West-Siberian Plain is one of the largest low-altitude accumulation plains on Earth. It developed within the Epihercynian West-Siberian plate, the basement of which is composed by intensely deformed Palaeozoic deposits. This basement is covered by unconsolidated, marine and continental Mesozoic-Cenozoic sediments (clay, sandstone, marl and others) of over $2 \mathrm{~km}$ thick (within basement troughs up to 3-4 km) (Shatskiy, 1973).
Most of the Paleogene deposits on the WestSiberian plain are buried under a thick cover of the Neogene-Quaternary deposits (Shatskiy, 1973) so that they can be studied only in boreholes, many of which have been drilled in the southern part of the West-Siberian Plain. Their locations are spread evenly over the plain, in Transuralia and, to a lesser extent, the northern areas. Cores from these boreholes have been studied over many years, so that both the general stratigraphy of the Palaeogene of Western Siberia and the detailed lithostratigraphy of the 
West-Siberian Plain are to be found in the extensive literature. The present author has also dealt with several stratigraphic aspects (e.g. Podobina, 1998, 2003, 2009).

The Palaeocene foraminiferal assemblages of western Siberia have already been studied more than half a century, among many others by Freiman (1960), Lipman et al. (1960), Dain (1961), Subbotina \& Kiselman (1961) and Subbotina (1964). The most complete material on the Palaeocene and the Palaeogene was reported by Podobina (1998). The present contribution deals with the Danian and Selandian assemblages and zones that belong, as already found earlier, to the uppermost Gankinskaya Suite (Gankinskian Horizon) and the Talitskaya Suite (Talitskian Horizon) (local and regional stratigraphic subunits; see Table 1). A section of borehole 1-r, drilled in the Novo-Loginovo area, provides the best record for tracing the marginal foraminiferal assemblages and their zones that occur principally in the central district of Western Siberia (sensu Podobina \& Kseneva, 2005). The marine sedimentary conditions were fairly stable there, so that the transitional Danian-Selandian strata could be dis- tinguished on the basis of foraminifers within numerous sections of boreholes in Western Siberia (Fig. 1). The 1-r borehole section was therefore chosen as the object of the present study (Table 1).

\section{Materials and biostratigraphy}

The Danian marine deposits of Western Siberia are known from Transuralia (in Russian 'Zauralye' ), which is the geographical name of the part of the West-Siberian Plain adjacent to the eastern slope of the Ural mountains; it covers the basins of the $\mathrm{Ob}^{\prime}$ and Tobol rivers (Fig. 1 ) and the Omsk Depression in the South-West. They are rare in the central district of the WestSiberian Plain (the Ob-Irtysh interfluve near Novyi Vasyugan) and are considered to represent the regions of the deepest subsidence of the Mesozoic-Cenozoic sediments (Aleskerova et al., 1957). They have also been found in the East within the almost continuous CretaceousPalaeogene sections of the Ust'-Tym Depression and in some sections of the $\mathrm{Ob}^{\prime}$ Basin (in Russian: Priobye) (Podobina, 1998). In the

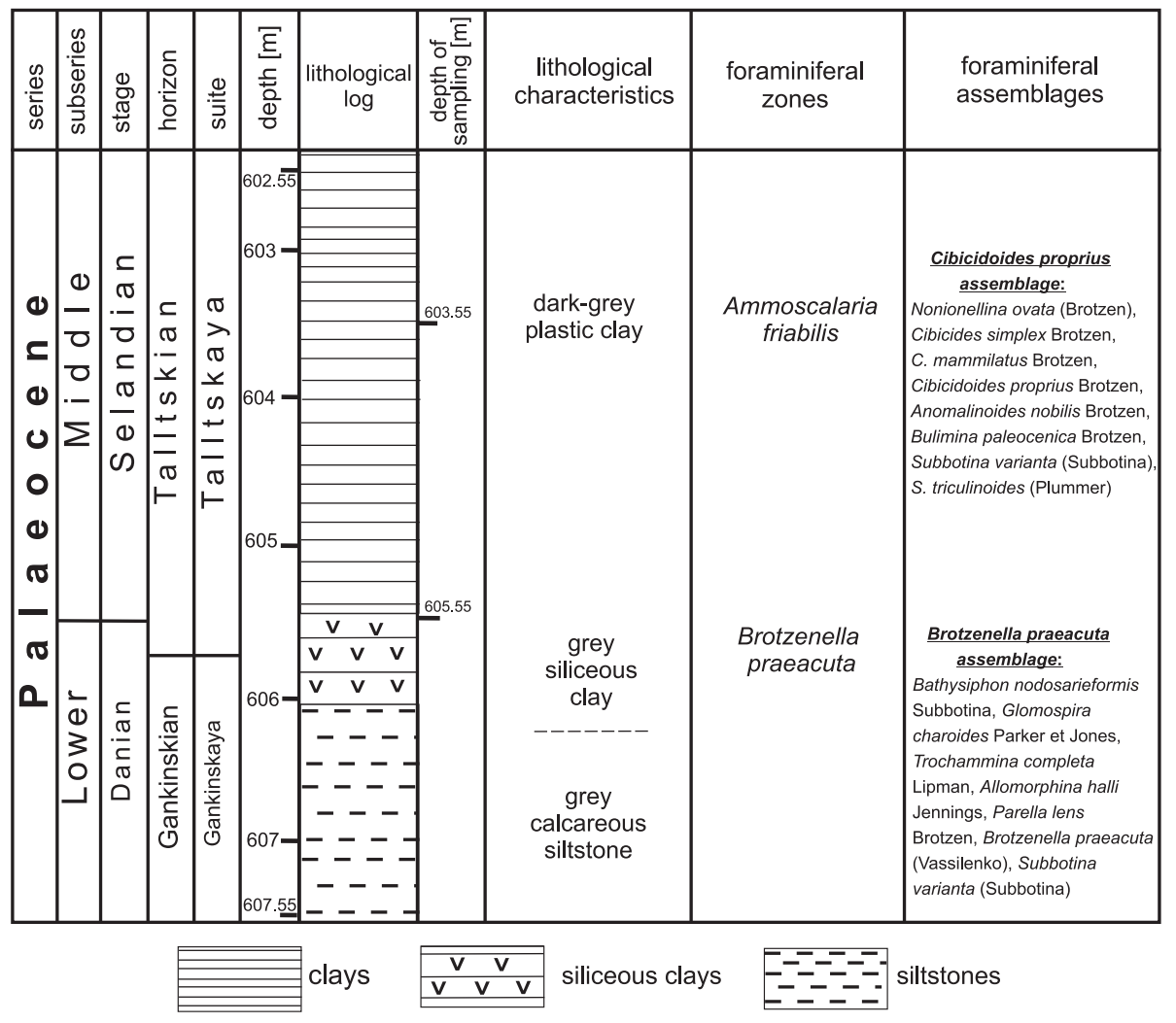

Table 1. Lithological and foraminiferal characteristics of the part of the section (borehole 1-r) under study. 
above regions, the uppermost Gankinskaya Suite of the Gankinskian Horizon is usually attributed to the Danian Stage; the sediments of the suite become here arenaceous, less calcareous, but sometimes slightly siliceous, and they seem to develop gradually from the overlying deposits of the Talitskaya Suite of the Talitskian Horizon (Table 1) (Podobina, 1998).

In 1937 Dain originally distinguished (without publishing) the Clavulina parisiensis - Anomalina ammonoides var. acuta assemblage from this part of the section near settlement Shumikha on the eastern slope of the Ural Mountains (and described it in Dain, 1961). The zone of the same name was also established by Dain (1961) in the sedimentary body composed of the somewhat siliceous light-grey clays. It was initially assigned by her to the Danian. Subbotina and Kiselman (1961) later designated this zone as Anomalina praeacuta and dated it also as Danian. Podobina (1975) assigned this species to the genus Brotzenella, that is Brotzenella praeacuta.

The Danian assemblage distinguished by Dain (1961) is similar in its taxonomy to those found in several sections of Transuralia and the central district of the West-Siberian Plain (in the Omsk Depression, including Novo-Loginovo,

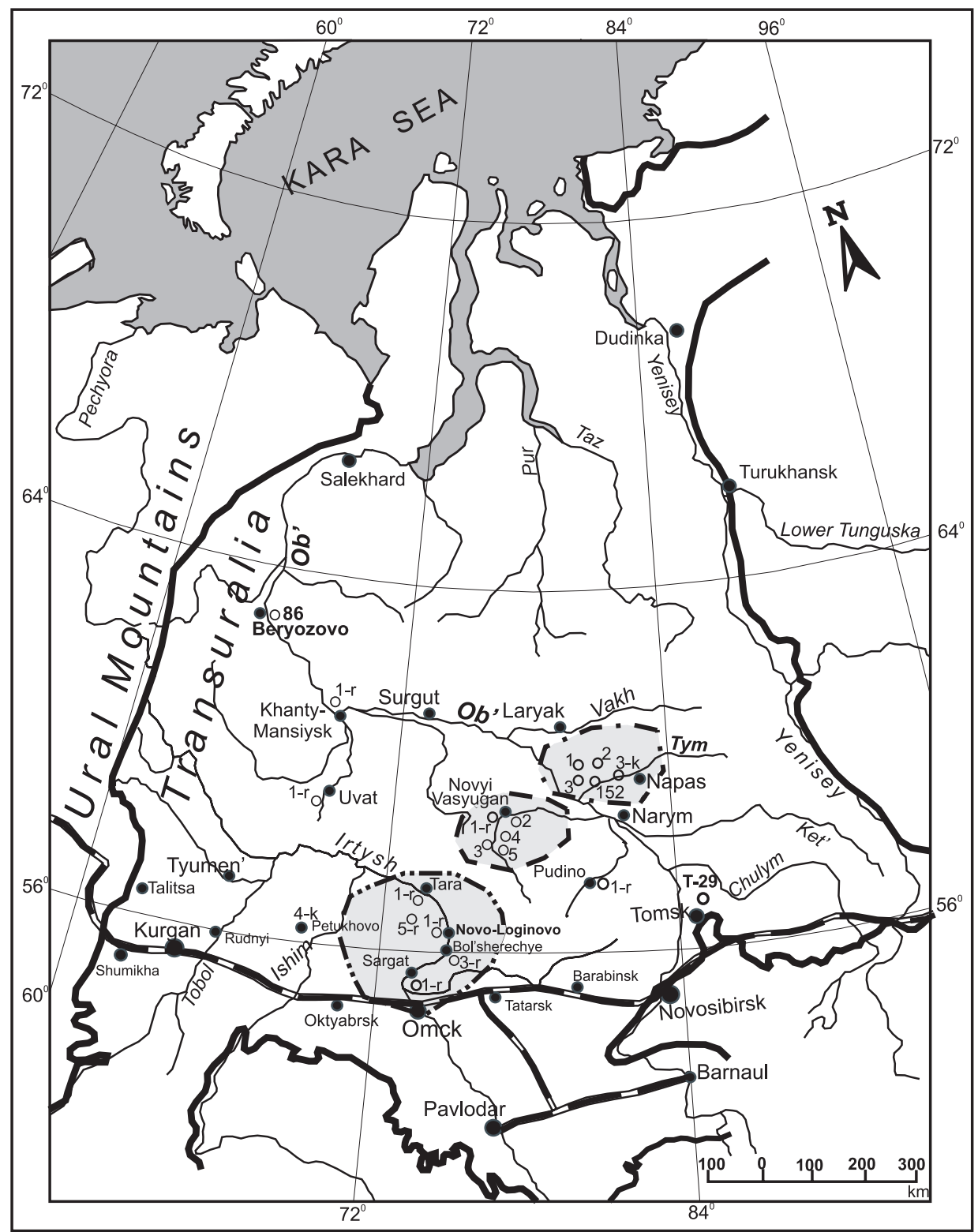

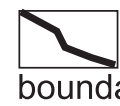

boundary of the West-Siberian Plain

O̊1-r boreholes: $0-k$ - key b., $0-r$ - rotary $b$.

1,2 - prospecting $b$.

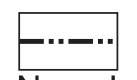

Novo-Loginovskaya mining area

(Omsk Depression)

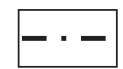

Payduginskaya mining area

(Ust'-Tym Depression)

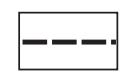

the Western

mining area
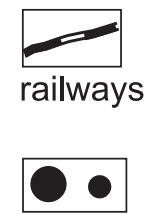

towns, settlements

Fig. 1. Locations of the boreholes with sections under study. 


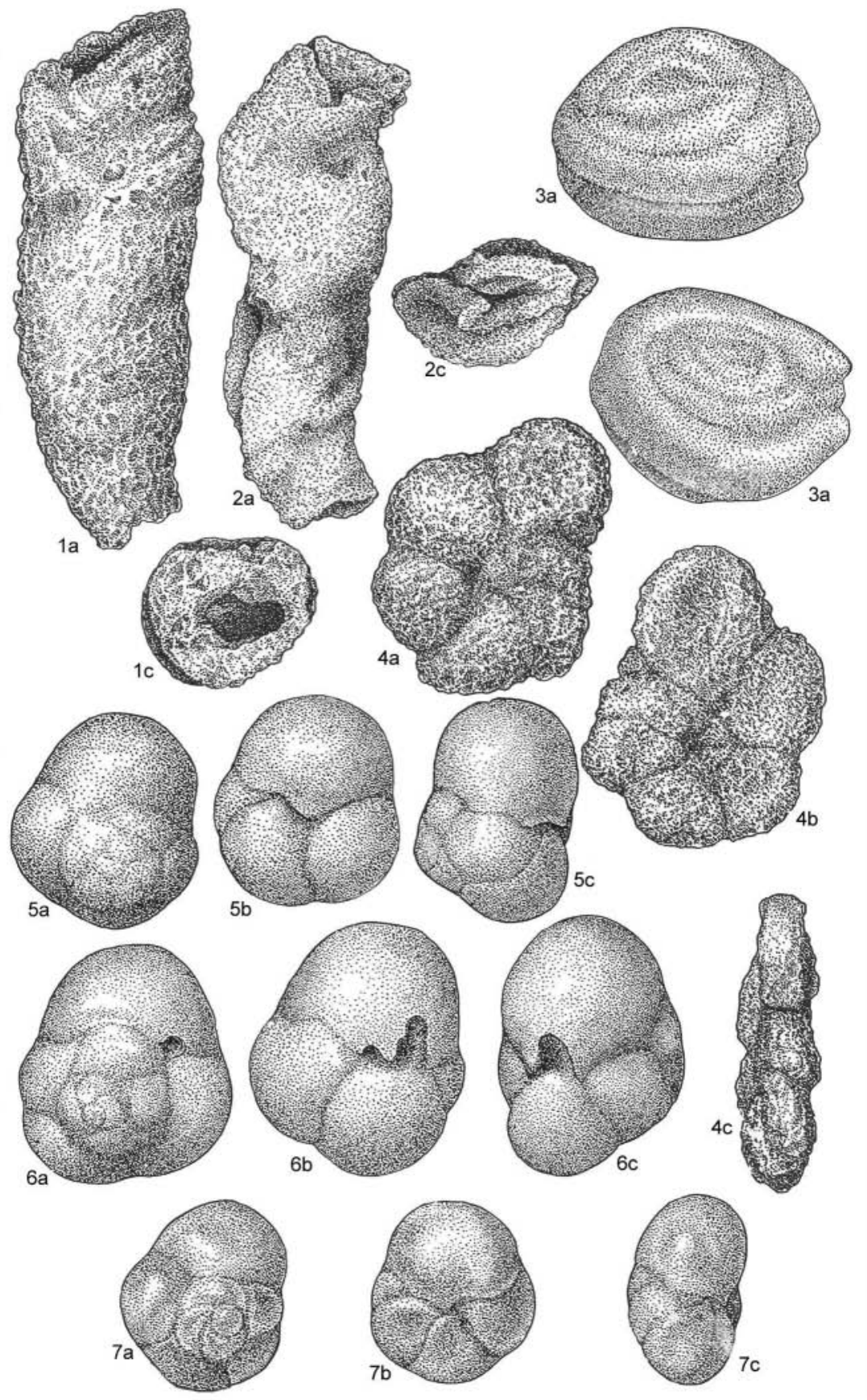

Plate I. Foraminifers from the upper beds of the Gankinskian Horizon and transitional beds to the Talitskian Horizon (Danian, WestSiberian Plain); borehole 1-r (near Novo-Loginovo), depth 607.55$602.55 \mathrm{~m}$ ( $2 \mathrm{~m}$ from the end of the core). All specimens are stored in the Micropaleontological Department of the Paleontological Museum of Tomsk State University. Figs. 1-2: Bathysiphon nodosarieformis Subbotina; specimens 3115, 3116; magnification x100; a - lateral view; c - apertural view.

Fig. 3: Glomospira charoides Parker et Jones, specimen 3117, x100; a lateral view.

Fig. 4: Trochammina completa Lipman, specimen 3118 , x60; a - dorsal view; b - ventral view; c - apertural view.

Figs. 5-7: Allomorphina halli Jennings, specimens 3118a, 3119, 3120, x100; a - dorsal view; b ventral view; c - apertural view.

Sargat, Bolsherechye, Tara), as mentioned by Podobina (1998). In the East, Danian beds with the Bathysiphon nodosarieformis - Glomospira charoides assemblage were found in similar deposits of continuous Cretaceous-Palaeogene sections (Podobina, 1990, 2009) (Fig. 1).

In addition, Selandian foraminiferal assemblages and the associated zonal subunits have been studied. The Ammoscalaria incultus var. friabilis Zone has been described from the overlying Talitskaya Suite (Lipman et al., 1960; Subbotina, 1964); it was renamed by the present author as the Ammoscalaria friabilis Zone (Podobina, 1975). This zone is correlatable in the East (the Ust-Tym Depression) with beds containing the Cyclammina coksuvorovae assemblage, and in the South-East with beds containing the Cibicidoides proprius assemblage, which is also known from numerous sections in the western and central districts of the West- 
Plate II. Foraminifers from the upper beds of the Gankinskian Horizon and transitional beds to the Talitskian Horizon (Danian, WestSiberian Plain): borehole 1-r (near Novo-Loginovo), depth 607.55$602.55 \mathrm{~m}$ ( $2 \mathrm{~m}$ from the end of the core).; Magnification x100. All specimens are stored in the Micropaleontological Department of the Paleontological Museum of Tomsk State University.

Figs. 1-2: Parella lens Brotzen, specimens 3121, 3122; a - dorsal view; b - ventral view; c - apertural view.

Fig. 3: Brotzenella praeacuta (Vassilenko), specimen 3123; a - dorsal view; b - ventral view; c - apertural view.

Figs 4-5: Subbotina varianta (Subbotina), specimens 3124, 3125; a - dorsal view; b - ventral view; c - apertural view.
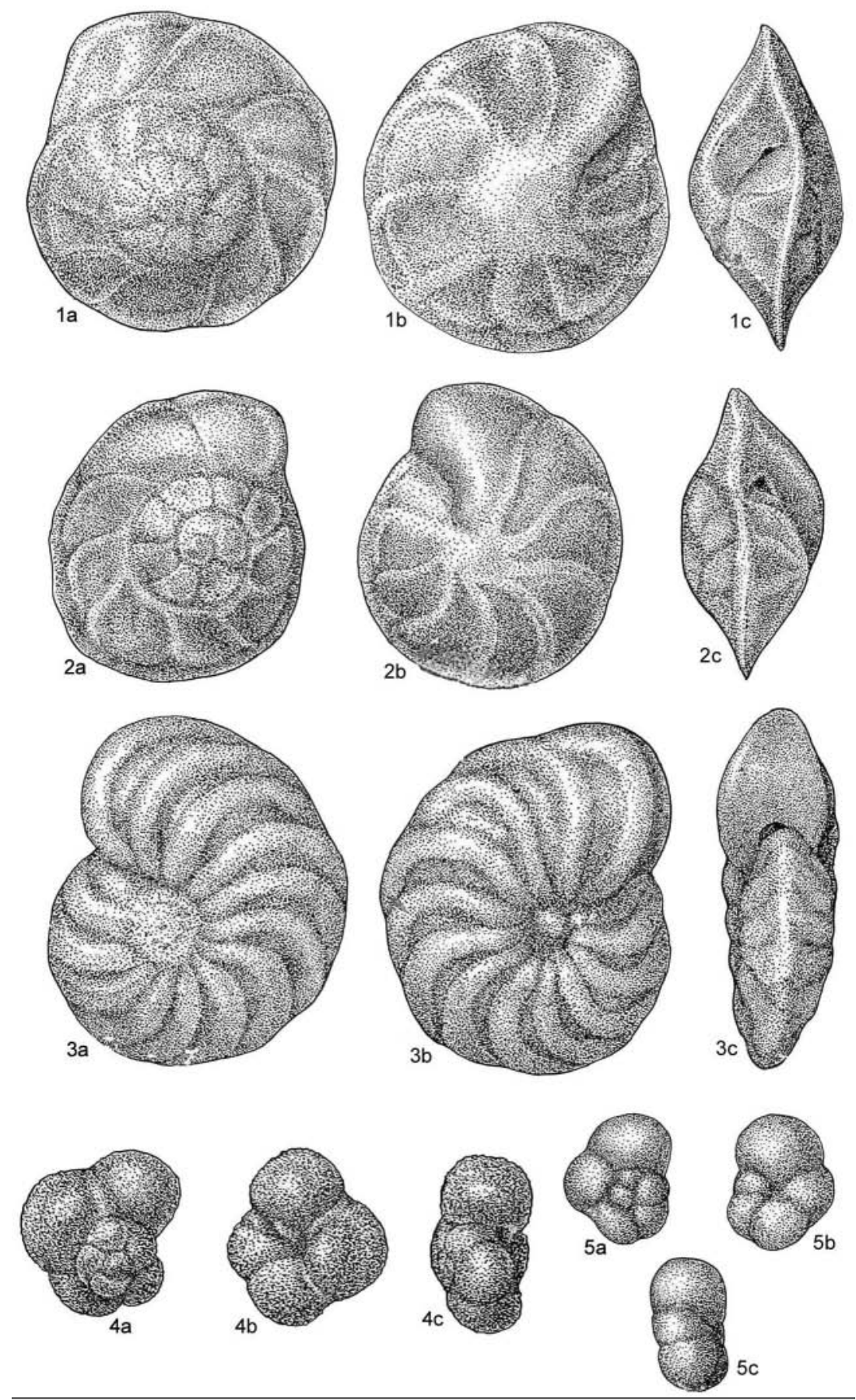

Siberian Plain. All Palaeocene foraminiferal assemblages studied by the present author are depicted in a monograph and some less extensive works (Podobina, 1998, figs 5-14, chapter III; 2003, plates I-VIII; 2008, plates I-III.).

The Danian and Selandian zones and the beds with index-species have been revised by the present author. In addition to the DanianSelandian foraminiferal collections that have been revised by the present author earlier, new

data on foraminiferal occurrences have later become available from the south-eastern area of Western Siberia (borehole T-29 in the surroundings of Tomsk) (Podobina, 2009). The previously studied deposits have been analysed again as regards the transitional Cretaceous - Palaeogene strata from the section of borehole 1-r ; this borehole yielded for the first time samples from a depth of 607.55-602.55 m, where two assemblages (the Brotzenella praea- 

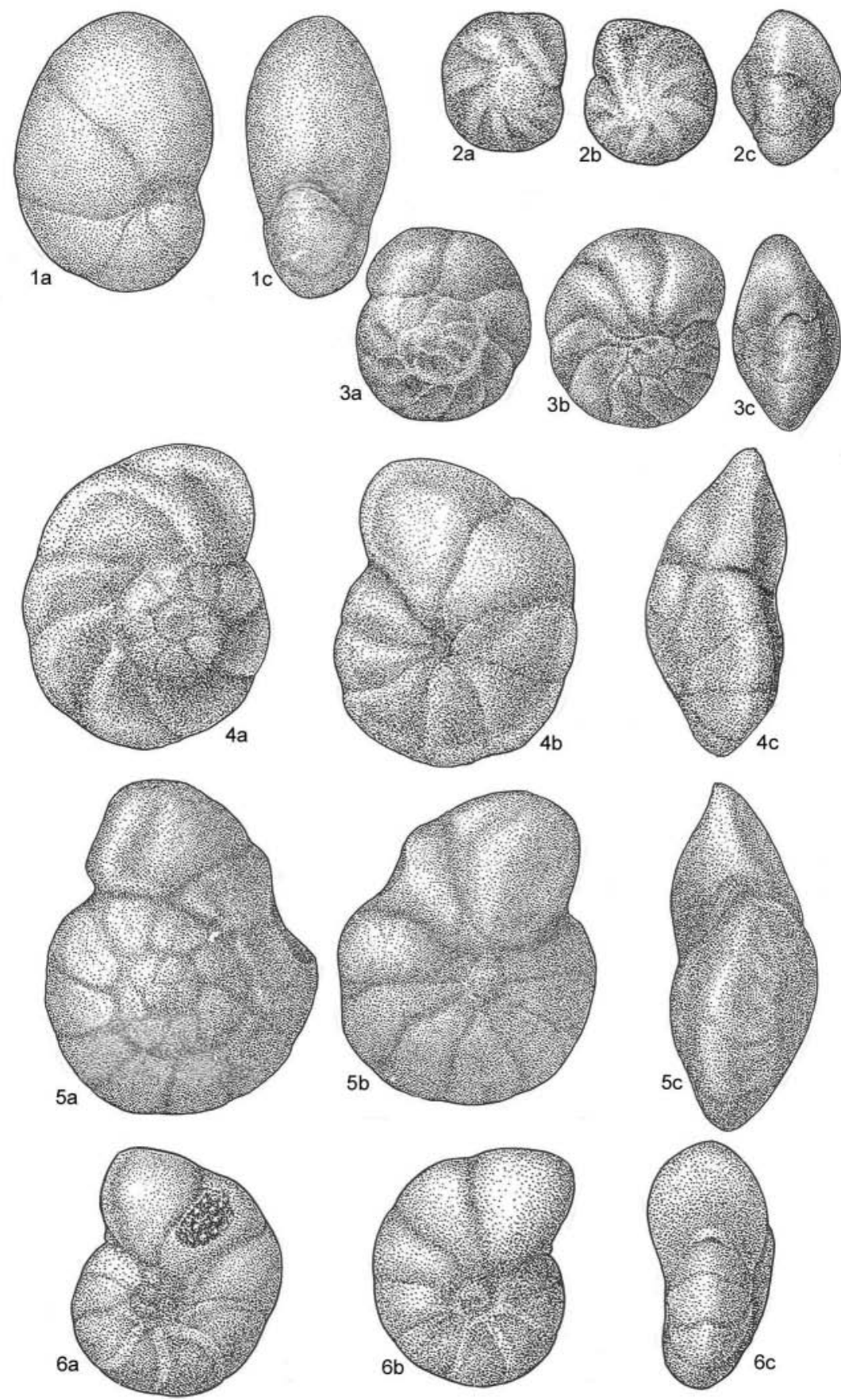

Plate III. Foraminifers from the Talitskian Horizon (Selandian, WestSiberian Plain): borehole 1-r (near Novo-Loginovo), depth 607.55$602.55 \mathrm{~m}$ (1 m from the beginning of the core); Magnification $x 100$. All specimens are stored in the Micropaleontological Department of the Paleontological Museum of Tomsk State University. Fig. 1: Nonionellina ovata (Brotzen), specimen 3100; a - lateral view, c - apertural view.

Fig. 2: Cibicides simplex Brotzen, specimen 3101; a - dorsal view; b - ventral view; c - apertural view.

Fig. 3: Cibicides mammilatus Brotzen, specimen 3102; a - dorsal view; b - ventral view; c - apertural view.

Figs. 4-5: Cibicidoides proprius Brotzen, specimens 3103, 3104; a - dorsal view; b - ventral view; c - apertural view.

Fig. 6: Anomalinoides nobilis Brotzen, specimen 3105; a - dorsal view; b - ventral view; c - apertural view.

cuta and the Cibicidoides proprius assemblages) could be distinguished instead of the single Danian-Palaeocene assemblage that had no established index species and that was described by Freiman (1960). Both newly distinguished assemblages are composed mainly of calcareous benthic and planktonic forms (Plates I-IV).

\section{Results}

The "West-Siberian common Danian - Paleocene" assemblage of foraminifers, originally established by Freiman (1960) from borehole 1-r (deep-water facies of the Novo-Loginovo area), has not been carefully studied, nor have index species been distinguished or described. Podobina (1990, 1998, 2009) has identified this assemblage elsewhere in Western Siberia, how- 
Plate IV. Foraminifers from the Talitskian Horizon (Selandian, WestSiberian Plain): borehole 1-r (near Novo-Loginovo), depth 607.55$602.55 \mathrm{~m}$ (1 $\mathrm{m}$ from the beginning of the core).; Magnification $x 100$. All specimens are stored in the Micropaleontological Department of the Paleontological Museum of Tomsk State University. Figs. 1-2: Anomalinoides nobilis Brotzen, specimens 3106, 3107; a - dorsal view; b - ventral view; c - apertural view.

Figs. 3-4: Bulimina paleocenica Brotzen, specimens 3108, 3109; a - lateral view; c - apertural view. Figs. 5-6: Subbotina varianta (Subbotina), specimens 3110, 3111; a - dorsal view; b - ventral view; $\mathrm{c}$ - apertural view.

Figs. 7-8: Subbotina triloculinoides (Plummer), specimens 3112, 3113; a - dorsal view; b - ventral view; $\mathrm{c}$ - apertural view.
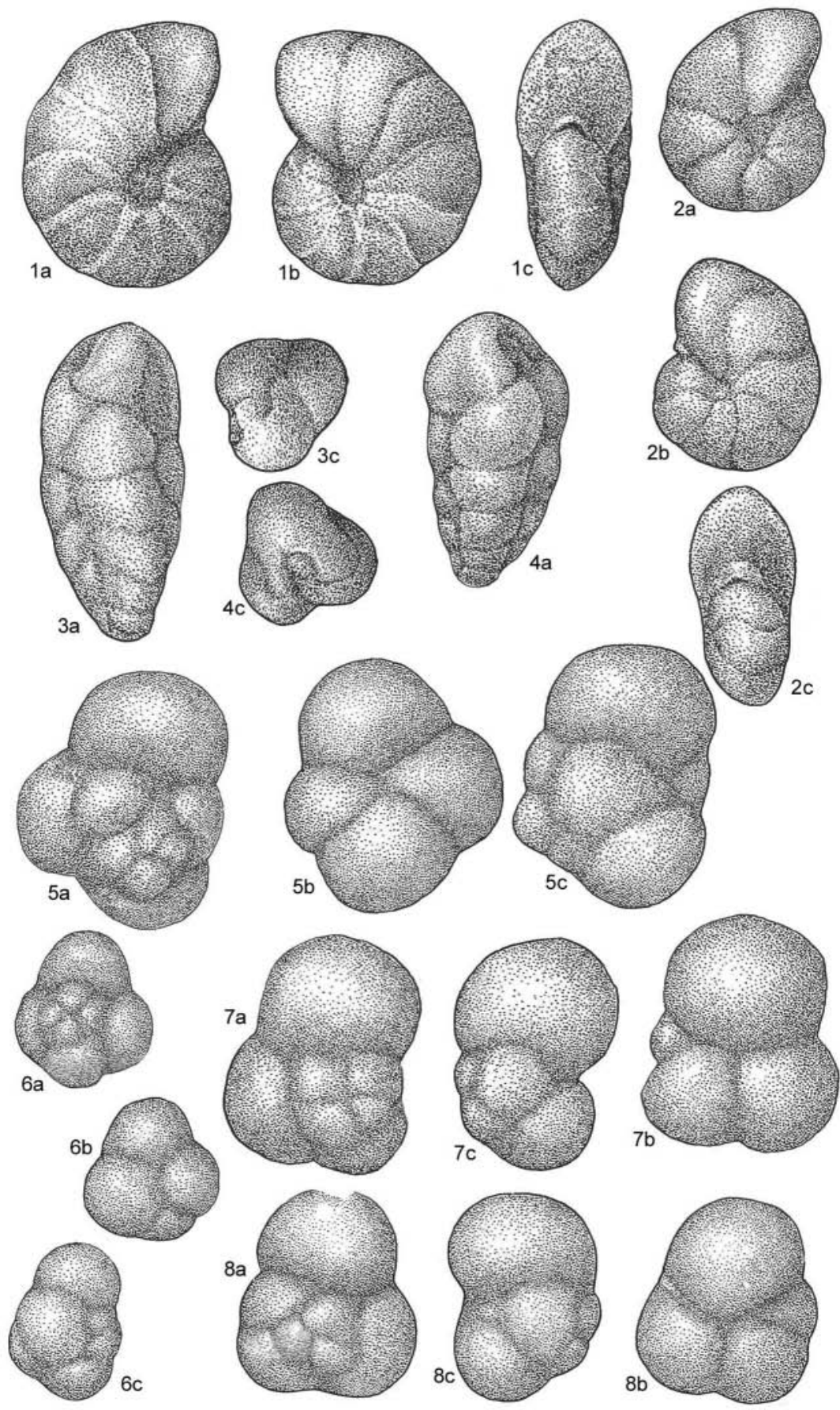

ever, describing its species composition and establishing Brotzenella praeacuta as its indexspecies, so that the Brotzenella praeacuta Zone could be established. This Danian Brotzenella praeacuta assemblage was studied by the present author from numerous sections in Western Siberia. The Danian foraminiferal species from borehole 1-r are illustrated in Plates I and II. Among the most characteristic species composing the Danian assemblage from this section are Gaudryina gigantica (Subbotina), Clavulina parisiensis d'Orbigny, Parella lens Brotzen, Cibicides spiropunctatus Gallowey et Morrey, Anomalina danica (Brotzen), Brotzenella praeacuta (Vassilenko), and Lenticula inusitata Kisselman (Podobina, 2009).

In the eastern part of Western Siberia, within the Ust'Tym sections (the Payduginskaya mining area) with the assumed Danian shallow facies, the following species have been re- 
corded: Bathysiphon nodosarieformis Subbotina, Glomospira gordialiformis Podobina, G. charoides Parker et Jones, Trochamminoides lamentabilis Podobina, Labrospira granulosa (Lipman), Adercotryma horrida (Grzybowski), Spiroplectammina sp. (aff. S. kazanzevi Dain) and Trochammina completa Lipman. These species jointly form the Bathysiphon nodosarieformis - Glomospira charoides assemblage (Podobina, 1998, 2003, 2008) (Table 2).

Among the calcareous benthic forms of the Brotzenella praeacuta assemblage, sparse planktonic species are encountered, which form the basis for the zonal subdivision in the column 'Unified Stratigraphic Scheme, 2001' of Table 2. These Palaeocene zones (including the Danian) of the Boreal Realm have been correlated with the coeval zones of Berggren and Pearson (2005) that contain some common species from the Tethyan Realm.

In the International Stratigraphic Guide (ISG) there are no analogues to the Russian 'beds with fauna (flora)' (in our case 'beds with foraminifers'), which are subsidiary biostratigraphic units. According to the Stratigraphic Code of Russia (2006), chapter VII, Article VII.10, "Beds with fauna (flora) represent deposits containing remains of organisms or com- posed of them but not conforming the requirements imposed upon a biostratigraphic zone. Such beds are established in deposits where either no remains of organisms are encountered in the underlying and overlapping formations or they are rare in occurrence in them."

The beds with the Bathysiphon nodosarieformis - Glomospira charoides assemblage were primarily established by the present author in borehole 1 (depth $470 \mathrm{~m}$ ) of the Ust'-Tym Depression (Fig. 1). The assemblage is dominated by primitive forms along with the more advanced species Trochamminoides lamentabilis Podobina, Labrospira granulosa (Lipman), Haplophragmoides fastosus Podobina, and Adercotryma horrida (Grzybowski). The Bathysiphon nodosarieformis - Glomospira charoides assemblage was also distinguished in boreholes 2, 3, 152 of the Ust'-Tym Depression (Fig. 1). A foraminiferal assemblage of a somewhat different taxonomical composition was traced in a borehole in the surroundings of Novyi Vasyugan; it was distinguished from the transitional deposits of the Gankinskaya Suite to the Talitskaya Suite, that are composed of the dark-grey compact silty clay. A small number of the species Ammodiscus glabratus Cushman et Jarvis, Glomospira charoides Parker et Jones, G. gordialiformis

\begin{tabular}{|c|c|c|c|c|c|c|}
\hline \multirow{3}{*}{\begin{tabular}{|c|} 
\\
0 \\
0 \\
-2 \\
0 \\
0 \\
0
\end{tabular}} & \multirow{3}{*}{\begin{tabular}{l|}
0 \\
0 \\
0 \\
- \\
$\vdots$ \\
0 \\
0 \\
0 \\
0 \\
3 \\
0 \\
0
\end{tabular}} & \multirow[b]{3}{*}{ 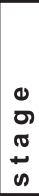 } & \multicolumn{2}{|c|}{ zones of planktonic foraminiferas } & \multirow{2}{*}{\multicolumn{2}{|c|}{$\begin{array}{c}\text { zones and beds } \\
\text { of benthic foraminiferas } \\
\text { of western Siberia }\end{array}$}} \\
\hline & & & \multirow{2}{*}{$\begin{array}{c}\text { Tethyan belt } \\
\text { Berggren \& Pearson } \\
(2005)\end{array}$} & \multirow{2}{*}{$\begin{array}{c}\text { boreal belt } \\
\text { Unified Regional } \\
\text { Stratigraphic Scheme } \\
(2001)\end{array}$} & & \\
\hline & & & & & $\begin{array}{c}\text { foraminiferal } \\
\text { zones } \\
\text { (Podobina, 2009) } \\
\end{array}$ & $\begin{array}{c}\text { beds with } \\
\text { foraminiferas } \\
\text { (Podobina, 2009) }\end{array}$ \\
\hline \multirow{4}{*}{\multicolumn{2}{|c|}{$\begin{array}{c} \\
z \\
z\end{array}$}} & \multirow{4}{*}{ 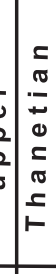 } & M. velascoensis & \multirow[b]{2}{*}{ Acarinina acarinata } & \multirow{4}{*}{$\begin{array}{l}\text { Glomospira } \\
\text { gordialiformis, } \\
\text { Cibicidoides } \\
\text { favorabilis }\end{array}$} & \multirow{4}{*}{$\begin{array}{l}\text { Glomospira } \\
\text { gordialiformis, } \\
\text { Cyclammina } \\
\text { coksuvorovae }\end{array}$} \\
\hline & & & Ac. soldadoensis - GI. pseudomenardii & & & \\
\hline & & & \multirow[t]{3}{*}{ Acarinina subsphaerica } & $\begin{array}{c}\text { Acarinina } \\
\text { subsphaerica }\end{array}$ & & \\
\hline & & & & \multirow{2}{*}{ Igorina djanensis } & & \\
\hline 0 & \multirow{4}{*}{$\frac{0}{\delta}$} & = & & & \multirow{4}{*}{$\begin{array}{c}\text { Ammoscalaria } \\
\text { friabilis }\end{array}$} & \multirow{4}{*}{ 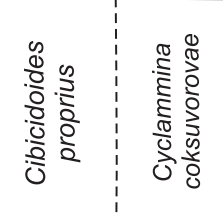 } \\
\hline 0 & &. & Gl. pseudomenardii - P. variolaria & \multirow{2}{*}{$\begin{array}{c}\text { Morozovella } \\
\text { conicotruncata }\end{array}$} & & \\
\hline \begin{tabular}{|l|} 
\\
\end{tabular} & & $\begin{array}{l}0 \\
\frac{1}{2} \\
\end{array}$ & Igorina albeari & & & \\
\hline-1 & & $\overline{0}$ & Igorina pusilla & Morozovella angulata & & \\
\hline$a$ & \multirow{4}{*}{$\begin{array}{l} \\
0 \\
3 \\
0 \\
0\end{array}$} & \multirow{4}{*}{$\begin{array}{l}\Sigma \\
\sigma \\
-\bar{c} \\
\sigma \\
0\end{array}$} & $\begin{array}{c}\text { P. uncinata } \\
\text { Gl. compressa - } \\
\text { Praemurica inconstans }\end{array}$ & Acarinina inconstans & \multirow{4}{*}{$\begin{array}{c}\text { Brotzenella } \\
\text { praĺacuta }\end{array}$} & \multirow{4}{*}{$\begin{array}{l}\text { Bathysiphon } \\
\text { nodosarieformis, } \\
\text { Glomospira } \\
\text { charoides }\end{array}$} \\
\hline & & & Subbotina triloculinoides & $\begin{array}{c}\text { Globoconusa } \\
\text { daubjergensis }\end{array}$ & & \\
\hline & & & P. pseudobulloides & \multirow[t]{2}{*}{ Euglobigerina taurica } & & \\
\hline & & & $P$. eugubina \& G. cretacea & & & \\
\hline
\end{tabular}

Table 2. Correlations between planktonic and benthic foraminiferal zones and beds. 
Podobina and Brotzenella cf. praeacuta (Vassilenko) were recorded from these sediments in borehole 4 (depth 415 m; Novyi Vasyugan area, Fig. 1).

In another section of the Novyi Vasyugan area (borehole 5, depth 443 m; Fig. 1), rare occurrences of the Bathysiphon nodosarieformis - Glomospira charoides assemblage, in which primitively arranged species were prevailing, were found in dark-grey silty clays with light-grey sand inclusions: Bathysiphon nodosarieformis Subbotina, Glomospira charoides Parker et Jones, and G. gordialiformis Podobina. In addition, the more advanced forms Heterostomella aff. foveolata (Marsson) and Nodosaria aspera (Reuss) are present.

An assemblage of similarly impoverished composition dominated by sugar-white, primitive forms was recorded from borehole 86 (depth 273-268 m) in northern Transuralia (near Beryozovo) (Fig. 1). Foraminifers of the Bathysiphon nodosarieformis - Glomospira charoides assemblage, including Bathysiphon nodosarieformis Subbotina, Hyperammina inferbulbata Bulatova, Ammodiscus glabratus Cushman et Jarvis, Glomospira charoides Parker et Jones, Cribrostomoides paleogenicus Podobina, Recurvoidella lamella (Grzybowski), Spiroplectammina kasanzevi Dain, and Clavulina parisiensis d'Orbigny were found in greenish-grey fragmented micaceous clays admixed with grey fine-grained sand. Specimens of the genera Bathysiphon and Spiroplectammina dominated (up to ten specimens in all five samples; depth 273-268 m); the other species were less common (up to five specimens).

It should be noted that the amounts of species in all studied samples usually do not exceed five specimens. In addition to the index species, Spiroplectammina kasanzevi Dain and Clavulina parisiensis d'Orbigny were the most characteristic of this part of the borehole section. The presence of relic Late Cretaceous (Late Maastrichtian) species is, obviously, the most characteristic of this assemblage, along with the dominance of the fairly primitive genera Bathysiphon, Hyperammina, Ammodiscus, and Glomospira.

The species indicate that the foraminifers lived in a limnic basin under a hydrological re- gime that was unfavourable for benthic calcareous forms, as opposed to the more deep-water facies of the Omsk Depression and southern Transuralia.

\section{The Early Palaeocene (Danian)}

\subsection{The Brotzenella praeacuta Zone}

(Plate I, Figs 1-7; Plate II, Fig. 1-5)

Dain (1961) originally established the Clavulina parisiensis - Anomalina ammonoides var. acuta Zone; Subbotina and Kiselman (1961) later distinguished the Anomalina praeacuta Zone. Podobina (1992) re-designated this zone to Brotzenella praeacuta.

\subsubsection{Lectostratotype}

Omsk Depression, near the village of Sargat, borehole 1-r, depth interval 558.83-552.18 $\mathrm{m}$. Clays grey, silty, slightly siliceous. Thickness $6 \mathrm{~m}$.

Zonal assemblage of characteristic foraminifers in the lectostratotype: Gaudryina gigantica (Subbotina), Clavulina parisiensis d'Orbigny, Lenticula inusitata Kisselman, Parrella lens Brotzen, Anomalina danica (Brotzen), Cibicides spiropunctatus Galloway et Morrey, Brotzenella praeacuta (Vassilenko).

Along with these benthic foraminifers, other sections of the zone contain sparse planktonic forms, among others Subbotina varianta (Subbotina), S. trivialis (Subbotina), S. triloculinoides (Plummer). The base of the zone is established by the appearance of the zonal species and by the diagnostic assemblage. Calcareous foraminifers dominate throughout, with Rotaliidae prevailing. The zone is traceable in the uppermost beds of the Gankinskian Horizon and in the transitional beds to the Talitskian Horizon.

\subsubsection{Occurrence}

The West-Siberian Plain. In the eastern part of Western Siberia (the Ust'-Tym Depression) beds encompassing the Bathysiphon nodosarieformis - Glomospira charoides assemblage correspond to those with the Brotzenella praeacuta Zone. 
As Subbotina \& Kiselman (1961) indicated, the presence of numerous relic Late Maastrichtian forms is characteristic of the foraminiferal assemblages of the Danian of Western Siberia and also for other regions. They reported the presence of two types of the Danian foraminiferal assemblages in Western Siberia. One is characterized by the presence of the above-listed species of planktonic foraminifers. In some sections, they are joined by primitive agglutinated forms. The planktonic forms seem to be absent in the Tym sections, but primitive agglutinated foraminifers are present.

The second Danian assemblage has a more varied composition and includes mostly genera and species of Rotaliidae, Anomalinidae and other families. The planktonic forms are already present as Danian-Selandian taxa, such as Subbotina varianta (Subbotina), S. trivialis (Subbotina), and S. triloculinoides (Plummer).

\subsubsection{Stratigraphic position}

The Danian Stage in the lectostratotype of the Brotzenella praeacuta Zone. In the East (the Tym Basin), it can be correlated with beds containing Bathysiphon nodosarieformis - Glomospira charoides assemblage.

The Brotzenella praeacuta Zone seems to be correlatable with the Danian zones of planktonic foraminifers of the Tethyan Realm (Interdepartmental Stratigraphic Committee, 2001; Berggren \& Pearson, 2005) (Table 2).

\section{The Middle Palaeocene (Selandian) Talitskaya Suite and Talitskian Horizon}

The overlying marine deposits of the Middle Palaeocene are mainly represented by the Talitskaya Suite of the Talitskian Horizon.

The Talitskaya Suite was established in 1955 by Aleskerova and Osyko (Aleskerova et al., 1957). It is composed of dark-grey, sometimes almost black, silty, compact clays. The in situ conditions of the suite, its thickness and contacts with the under- and overlying deposits indicate that this suite is not retained in full measure in the eastern part of the Ob-Irtysh in- terfluve. The thickness of the suite ranges here commonly from 10 to $15 \mathrm{~m}$ (the thickness is up to $320 \mathrm{~m}$ in the stratotype near the village of Talitsa in the Sverdlovsk Region). The bottom beds of the suite are often completely waterworn, and only its top can be traced in the section.

\subsection{The central district}

In the central district of Western Siberia, the present author studied the Talitskaya Suite in boreholes 1, 4 and 5 of the Novyi Vasyugan area (Fig. 1). The Ammoscalaria friabilis assemblage was identified in borehole 1 (depth 600 m). As demonstrated before (Podobina, 1975), the Middle Palaeocene deposits contain the index-species Ammoscalaria friabilis (Ehremeeva).

The assemblage from borehole 1 (Novyi Vasyugan area) includes the following species: Bathysiphon nodosarieformis Subbotina, Psammosphaera laevigata White, Glomospira gordialiformis Podobina, Ammodiscus glabratus Cushman et Jarvis, Labrospira granulosa (Lipman), Quinqueloculina aff. moremani Cushman et Jarvis, Q. pulchra Putrja, Robulus discus Brotzen, Donsissonia laxata Podobina, Eponidus lunatus Brotzen, Cibicidoides proprius Brotzen, Evolutononion sibiricus (Lipman), Nonionellina ovata (Brotzen), Subbotina varianta (Subbotina), S. triloculinoides (Plummer), Protoglobobulimina ovata (Brotzen) and others. In addition to agglutinated tests, this assemblage contains calcareous forms (the 11 just-mentioned species, starting with Quinqueloculina) of the Selandian Cibicidoides proprius assemblage, which is widespread in Transuralia.

A large number of species composing this assemblage are known from the Selandian stratotype (island Sjælland or Seeland, Denmark); they were described by Brotzen (1948) from this stratigraphic level in southern Sweden. The West-Siberian taxa were compared with Selandian forms from Denmark by Podobina $(1998,2003,2008,2009)$.

The Selandian foraminiferal species from the borehole 1-r (Novo-Loginovo) are illustrated in Plates III and IV. 


\subsubsection{The Uvat borehole}

The most complete section of the Talitskaya Suite (and the Middle Palaeocene) has been studied in the Uvat key borehole, where this suite is $125 \mathrm{~m}$ thick, and where it can be divided on the basis of its lithology into an upper and a lower subsuite. The thickness of the lower subsuite approximates $80 \mathrm{~m}$, that of the upper subsuite is $45 \mathrm{~m}$.

The foraminiferal zones established in these subsuites have also different thicknesses. For example, the thickness of the lower beds in the Uvat borehole (the Selandian Ammoscalaria friabilis Zone) is $105 \mathrm{~m}$, and that of the upper beds (Thanetian Glomospira gordialiformis- Cibicidoides favorabilis Zone) is $20 \mathrm{~m}$. Consequently, the upper Thanetian zone of the central district comprises only the uppermost beds of the Talitskaya Suite and the lowermost beds of the Lyulinvorskaya Suite (Podobina, 1998, 2003, 2008).

\subsubsection{The Ammoscalaria friabilis Zone}

(Plate III, Figs 1-6; Plate IV, figs 1-8)

The Ammoscalaria incultus var. friabilis Zone has been established by Lipman (Lipman et al., 1960); then, the Ammoscalaria incultus - Cibicides incognitus Zone was established by Freiman (1960), afterwards the Ammoscalaria incultus Zone was established by Subbotina and Ushakova (Subbotina, 1964), and finally the Ammoscalaria friabilis Zone was established by Podobina (1975).

\subsubsection{Lectostratotype}

The Novyi Vasyugan key borehole 1-r, depth interval 584.65-543.44 m. Clays darkgrey, with a greasy feel, slightly siliceous. Thickness $41 \mathrm{~m}$.

The assemblage of characteristic foraminifers in the lectostratotype includes: Labrospira granulosa (Lipman), Haplophragmoides fastosus Podobina, Asanospira grzybowski (Mjatliuk), Cyclammina coksuvorovae Uschakova, Ammoscalaria friabilis (Ehremeeva), Ammomarginulina brevis (Lipman), Verneuilinoides paleogenicus (Lipman), Trochammina pentacamerata Lipman, and T. completa (Lipman) (Podobina, 1998).

The foraminiferal assemblages vary over the numerous sections. In some places, the num- bers of species are limited and the specimens are poorly preserved; tests are of intermediate or small size. The agglutinated quartz-siliceous benthos amounts to almost $90 \%$. Haplophragmiidae and Trochamminidae dominate.

The base of the zone is established by the appearance of the index species and characteristic species of the assemblage. At the upper boundary, the zone-specific and other species disappear.

\subsection{Northern Transuralia}

In northern Transuralia, the Ammoscalaria friabilis assemblage was recorded from a depth of 258-203 $\mathrm{m}$ in borehole 86 (near town Beryozovo), where the sediments consist of dark-grey, almost black, compact clay that is fragmented and contains local admixtures of glauconite. Agglutinated foraminifers are dominant in all samples, except those from the depths of $213 \mathrm{~m}$, $208 \mathrm{~m}$ and $203 \mathrm{~m}$, where they are sparse. Numerous calcareous forms of the Cibicidoides proprius assemblage were found from a depth of $233 \mathrm{~m}$, along with agglutinated foraminifers of the Ammoscalaria friabilis assemblage. This species was also found in the bottom and middle parts of the depth range 258-203 $\mathrm{m}$, whereas some calcareous species were traced together with agglutinated forms throughout the whole section of the Talitskaya Suite.

Podobina $(2003,2006,2008)$ studied the taxonomy of this assemblage, which resembles, as mentioned, that of the Selandian assemblages from Denmark and Sweden.

\subsubsection{Borehole 86}

In borehole 86, the Cibicidoides proprius assemblage of planktonic foraminifers from the lowermost beds of the Talitskaya Suite is the most diverse. A principally similar composition is known from the Omsk Depression (among others the section of borehole 1-r; Fig. 1 ; Table 1). The deposits with this assemblage are, together with the overlying beds assigned to the Ammoscalaria friabilis Zone (Podobina, 1975, 2003). 


\subsection{The Ust-Tym Depression}

In the Ust-Tym Depression (boreholes 2, 3, 152; Figure), at this stratigraphic level the beds are traced with a depauperated assemblage of agglutinated foraminifera and large cyclamminas designated by the present author (Podobina, 1990, 1998, 2003) as the Cyclammina coksuvorovae assemblage. Beds with this assemblage are correlatable with the Middle Paleocene Ammoscalaria friabilis Zone. Farther eastwardly and south-eastwardly, in the vicinity of town Tomsk (borehole T-29) the Cibicidoides proprius assemblage was distinguished. This assemblage contains the Selandian characteristic planktonic species Morozovella angulata White (Podobina, 2006, 2009).

The Selandian foraminiferal species from the section of borehole 1-r of the Novo-Loginovo area are illustrated by paleontological Plates III and IV.

\subsection{Occurrence and stratigraphic position}

\subsubsection{Occurrence}

Throughout western Siberia, most of the Talitskaya Suite, including the above zone, is assigned to the Selandian. Beds with the Cibicidoides proprius assemblage of the Brotzenella praeacuta Zone, established originally by Freiman (1960) from the Novo-Loginovo sections without specification of the index-species, are conventionally assigned to this suite. The present author has demonstrated that numerous species of benthic foraminifers from these beds are also distributed higher up in the Talitskaya Suite section. She re-designated the assemblage of benthic forms to the Cibicidoides proprius assemblage, which is also encountered in the Selandian lowermost part of the Talitskaya Suite. The Cibicidoides proprius assemblage is composed of the species Bolivinopsis scanica Brotzen, Spiroloculina alabamensis Cushman, Quinqueloculina pulchra Putrja, Discorbinella limbata (Brotzen), Donsissonia laxata Podobina, D. ornata Podobina, Eponides toulmini Brotzen, E. lunatus Brotzen, Gavelinella umbilicata (Brotzen), Cibicides simplex Brotzen, Cibicidoides proprius Brotzen, Evolutononion sibiricus
(Lipman), Nonionellina ovata (Brotzen), Protoglobobulimina risilla (Subbotina), and Bulimina ovata (d'Orbigny) (Podobina, 1998, 2009).

Planktonic species have been encountered together with the above benthic forms in the assemblage found in borehole 1-r (Novo-Loginovo) at a depth of 607.55 and $602.55 \mathrm{~m}$; Fig. 1); the species Subbotina varianta (Subbotina), S. trivialis (Subbotina), Acarinina aff. inconstans Subbotina have been identified. A study on the Cibicidoides proprius assemblage, which is very similar to a Swedish assemblage (Brotzen, 1948), demonstrated that the nearest analogue of the latter had been encountered in borehole 86 (Fig. 1). Beds with the Cibicidoides proprius assemblage in this borehole are confined to the lower and middle strata of the Talitskaya Suite.

\subsubsection{Stratigraphic position}

The Selandian stage in the lectostratotype of the Ammoscalaria friabilis Zone correlates with most of the Talitskaya Suite of the Talitskian Horizon.

Along with large Cyclamminae and other agglutinated forms, Podobina (1998, 2003, 2008) has distinguished calcareous benthic foraminifers in the Middle Palaeocene assemblage of the Tym Basin (borehole 3-k); they are the same species as in the Cibicidoides proprius assemblage found in the lower beds of the Talitskaya Suite that are widespread over the western part of the West-Siberian Plain. In the eastern part of Western Siberia (the Ust'-Tym Depression), the present author has recognised the beds with Cyclammina coksuvorovae confined to the Ammoscalaria friabilis Zone.

The Ammoscalaria friabilis Zone, which is assigned to the Selandian, seems to correlate with the planktonic foraminiferal zones (Interdepartmental Stratigraphic Committee, 2001; Berggren \& Pearson, 2005) (Table 2).

\section{Conclusions}

The study was aimed at Danian-Selandian benthic foraminiferal assemblages and the zonal subunits based on them. Whereas the present author's previous publications have 
reported data on the Palaeocene assemblages of agglutinated foraminifers, the present contribution deals with calcareous forms. These tests, collected from borehole 1-r near NovoLoginovo, are illustrated in Plates I-IV (see also Table 1).

Freiman (1960) has previously established one Danian-Palaeocene (principally Selandian) foraminiferal assemblage from this borehole (from a depth of 607.55-602.55 m) without specifying the index species. The present author has subdivided the sediments of this interval into two zones: a first one (607.55-602.55 $\mathrm{m} ; 2 \mathrm{~m}$ from the end of the core) containing the Danian Brotzenella praeacuta assemblage (Plates I-II), and a second one (607.55-602.55 m; $1 \mathrm{~m}$ from the top of the core of this interval) with the Cibicidoides proprius assemblage (Plates IIIIV). This sedimentary succession encloses the transition from the Danian to the Selandian and is traced mainly in the central part of western Siberia.

Thus, foraminiferal assemblages and zones of the Danian (Lower Palaeocene) and Selandian (Middle Palaeocene) were established from the complete section of the Novo-Loginovo borehole 1-r.

\section{Acknowledgements}

Professor D.P. Naydin has kindly donated samples from Denmark, thus providing the exceptionally abundant and carefully selected material for comparing West-Siberian and Danish Selandian forms. I consider it my duty to express my gratitude to him.

Dr. Maria Rose Petrizzo and Dr. Krzysztof Bąk offered constructive criticism of the manuscript and made important suggestions. I am very much obliged to them for their reviews and I greatly appreciate their assistance.

Professor William Berggren (Woods Hole Oceanographic Institute, Woods Hole, U.S.A.) has kindly provided me with a publication that contained important information. Many thanks are extended to him and his coauthor Dr P.N. Pearson (Cardiff University, United Kingdom).

I kindly appreciate the careful revision of my manuscript by Prof. Dr. Antonius J. van
Loon. Dr. Pawel Wolniewicz assisted me much in improving my manuscript and I deeply appreciate this.

\section{References}

Aleskerova, Z.T., Li, P.F., Osyko, T.I., Rostovtsev, N.N. \& Tolstikhina, M.A., 1957. Stratigrafiya mezozoyskikh i tretichnykh otlozheniy zapadnosibirskoy nizmennosti. [Stratigraphy of the Mesozoic and Tertiary deposits of the West-Siberian Plain]. Sovetskaya Geologiya (Soviet Geology) 55, 146-172. [in Russian]

Berggren, W.A. \& Pearson, P.N., 2005. A revised tropical to subtropical Paleogene planktonic foraminiferal zonation. Journal of Foraminiferal Research 35, 279298.

Brotzen, F., 1948. The Swedish Paleocene and its foraminiferal fauna. Sveriges Geologiska Undersökning, Ser. C 493 (Årsbok 42/2), 140 pp., 19 plates.

Dain, L.G., 1961. Nekotoryie vidy foraminifer melovykh otlozheniy Shumikhinskogo rayona Chelyabinskoy oblasti [Some foraminiferal species from the Cretaceous deposits of the Shumikhinskian District of the Cheliabinsk Region]. [In:] L.P. Grozdilova \& I.N. Ionina (Eds): Microfauna of the USSR. Collection 12. Gostoptekhizdat, Leningrad, 4-42, 2 plates. [in Russian]

Freiman, E.V., 1960. O novom datsko-paleotsenovom komplekse foraminifer Zapadnoy Sibiri [On a new Danian-Palaeocene foraminiferal assemblage of Western Siberia]. [In:] Proceedings of SNIIGGMS (Proceedings of Siberian Research Institute of Geology, Geophysics \& Minerals) 8, 212-215. [in Russian]

Interdepartmental Stratigraphic Committee of Russia, 2001. Unifitsirovannaya regional'naya stratigraficheskaya skhema paleogenovykh i neogenovykh otlozheniy zapadnosibirskoy nizmennosti. [Unified regional stratigraphic scheme of the Palaeogene and Neogene deposits of the West-Siberian plain], 2001. Siberian Research Institute of Geology, Geophysics and Mineral Resources (SNIIGGiMS), Novosibirsk. [in Russian]

Lipman, R.Kh., Burtman, E.S. \& Khokhlova, I.A., 1960. Stratigrafiya i fauna paleogenovykh otlozheniy zapadnosibirskoy nizmennosti. [Stratigraphy and fauna of the Palaeogene deposits of the West Siberian Plain]. Proceedings of All Union Geological Institute (VSEGEI), new series 28, 231 pp., 23 plates. [in Russian]

Podobina, V.M., 1975. Foraminifery verkhnego mela i paleogena zapadnosibirskoy nizmennosti, ikh znacheniye dlya stratigrafii. [The Late Cretaceous and Palaeogene foraminifers of the West-Siberian Plain and their significance for the stratigraphy]. Tomsk University Press, Tomsk, 264 pp., 40 plates. [in Russian]

Podobina V.M., 1990. Novyie dannyie po biostratigrafii paleotsena Zapadnoy Sibiri [New data on the Palaeocene biostratigraphy of western Siberia]. Byulleten' Moskovskogo obshchestva ispytateley prirody [Bulletin 
of the Moscow Society of Nature Testers], Geology branch 65/5, 61-67. [in Russian]

Podobina, V.M., 1992. Datskiy yarus Zapadnoy Sibiri [The Danian stage of western Siberia]. [In:] V.M. Podobina (Ed.): Materials on paleontology and stratigraphy of Western Siberia. Tomsk University Press, Tomsk, 80-83. [in Russian]

Podobina, V.M., 1998. Foraminifery i biostratigrafiya paleogena Zapadnoy Sibiri [Palaeogene Foraminifera and biostratigraphy of western Siberia]. "NTL" Press, Tomsk, 338 pp., 62 plates. [in Russian]

Podobina, V.M., 2003. Paleocene biota of the West Siberian. [In:] S.L. Wing, P.L. Gingerich, B. Schmitz \& E. Thomas (Eds): Causes and consequences of globally warm climates in the early Paleogene. Geological Society of America Special Paper 369, 181-204.

Podobina, V.M., 2006. Novyie dannyie po stratigrafii i foraminifery morskogo paleogena yugo-vostoka Zapadnoy Sibiri [Recent data on the stratigraphy and the marine Palaeogene foraminifers of south-eastern western Siberia]. [In:] Geology and mineral resources of South Siberia. Bulletin of Tomsk State University (Vestnik TGU) 104:, 17-21. [in Russian]

Podobina V.M., 2008. Paleocene foraminifera and biostratigraphy of Western Siberia. [In:] M.A. Kaminski \& R. Coccioni (Eds): Proceedings of the $7^{\text {th }}$ International Workshop on Agglutinated Foraminifera. Grzybowski Foundation Special Publication 13, 183-198, 3 plates.

Podobina, V.M., 2009. Foraminifery, biostratigrafiya verkhnego mela i paleogena Zapadnoy Sibiri [Foraminifers, biostratigraphy of the Upper Cretaceous and Palaeogene of western Siberia]. Tomsk State University Press, Tomsk, 432 pp., 73 plates. [in Russian]

Podobina, V.M. \& Kseneva, T.G., 2005. Upper Cretaceous zonal stratigraphy of the West Siberian Plain based on foraminifera. Cretaceous Research 26, 133-143.

Shatskiy, S.B., 1973. Marine and continental Palaeogene of Siberia. Novosibirsk, Nauka, 140 pp. [in Russian].

Stratigraphic Code of Russia, 2006. Chapter VII, item VII.10. St.-Petersburg, VSEGEI Press. [in Russian]

Subbotina, N.N. [Ed.], 1964. Foraminifery melovykh i paleogenovykh otlozheniy zapadnosibirskoy nizmennosti. [Foraminifera of Cretaceous and Palaeogene deposits of the West-Siberian Plain]. Nedra, Leningrad, 456 pp., 66 plates. [in Russian]

Subbotina, N.N. \& Kiselman, E.N., 1961. Mikrofaunisticheskaya zona Anomalina praeacuta v zapadnosibirskoy nizmennosti. [The microfaunal Anomalina praeacuta Zone in the West-Siberian Plain]. [In:] N.N. Rostovtsev (Ed.): Resolutions and proceedings of the interdepartmental session on the revision and refinement of the stratigraphic maps of the West-Siberian Plain. Gostoptekhizdat, Leningrad, 243-252. [in Russian]

Vasilenko, V.P., 1954. Anomalinidy. Iskopayemiye foraminifery SSSR. [Anomalinidae. The fossil Foraminifera of the USSR]. Proceedings of VNIGRI 80. Gostoptekhizdat, Leningrad, 280 pp., 36 plates. [in Russian]

Manuscript received 10 October 2010 revision accepted 17 April 2011 